\title{
BENTHIC FAUNA STATUS AS INDICATOR OF WATER QUALITY ASSESSMENT IN STREZHEVO ACCUMULATION
}

\author{
Rodne Nastova, Vasil Kostov, Natasha Gjorgovska, Vesna Levkov \\ "Ss. Cyril and Methodius" University in Skopje, Institute of Animal Science, \\ Blvd. Ilinden 92a, 1000 Skopje, Republic of Macedonia \\ rodne_nastova@yahoo.com
}

\begin{abstract}
In the period March-October 2009 in the water of Strezhevo accumulation, Shemnica River and the alimentation canal samples of water and sediment were being collected for multidisciplinal research, with special regard to the quantitative and qualitative composition of benthic fauna. The field study was organized in season intervals, and special attention was paid to the critical months (June, July, August) with the goal of following-up the dynamics of the changes in the accumulation. The obtained results shows that the dominant groups of bottom fauna are Oligochaeta, Ephemeroptera,Trichoptera, Diptera and Plecoptera. According to the used indicators (composition of macrozoobentos fauna) it was found that there is a serious worsening of the water quality in the ecosystem. Increased presence of biodegradable organic matters was noticed, especially in the summer period.
\end{abstract}

Key words: water quality; bottom fauna; assessment; worsening

\section{СТАТУСОТ НА БЕНТОСНАТА ФАУНА КАКО ИНДИКАТОР ЗА ОДРЕДУВАЊЕ НА КВАЛИТЕТОТ НА ВОДАТА ВО АКУМУЛАЦИЈАТА СТРЕЖЕВО}

\begin{abstract}
Во периодот март-октомври 2009 година од акумулацијата Стрежево, реката Шемница и алиментациониот канал се земени примероци од вода и седименти за мултидисциплинарни истражувања со посебен осврт на хидробиолошките испитувања и добиените резултати се презентирани во овој труд. Теренските истражувања беа организирани во сезонски интервали, а посебно внимание беше посветено на критичните месеци (јуни, јули, август) со цел да се следи динамиката на промените во акумулацијата. Резултатите од истражувањата на квалитативниот и квантитативниот состав на бентосната фауна укажуваат на доминација на следните групи: Oligochaeta, Ephemeroptera,Trichoptera, Diptera и Plecoptera. Составот на микрозообентосната фауна навестува дека постои сериозно влошување на квалитетот на водата во проучуваниот екосистем. Зголеменото присуство на биоразградливи органски материи беше забележано особено во летниот период.
\end{abstract}

Клучни зборови: квалитет на вода; фауна на дното; влошување

\section{INTRODUCTION}

By the amount of accumulated water, Strezhevo is ranked in the sixth place in our country.

The accumulation is $7 \mathrm{~km}$ long and $29 \mathrm{~m}$ deep. Strezhevo dam is a high embankment earth barrage with central clay core and upstream-downstream gravel support body, erected on Shemnica River, $24 \mathrm{~km}$ upstream from its confluence into Crna River and $1.5 \mathrm{~km}$ downstream from the village of Strezhevo. Its construction created an accumulation space with useful volume that enables: providing amounts of water necessary for irrigation of part of Pelagonia, drinking and technological water for livestock, partial replenishment up to the required amounts of un-processed water for the needs of JP "Vodovod" - Bitola, providing part of the needs for technological water for part of the industry, and protection from flooding a part of Pelagonia.

The area covered by the hydrosystem Strezhevo is located in the south-west part of R. Macedonia, occupying an area of $715 \mathrm{~km}^{2}$. It includes: the east side of Baba Mountain massif, the confluent area of Shemnica River, the Strezhevo dam profile and the part of Pelagonia confined by 
Shemnica River, Crna River and MacedonianGreek border.

The water from the accumulation primarily used for irrigation of the arable area in the Bitola part of Pelagonia, in a great deal enables solving the problem of supplying Bitola and the nearby villages with quality drinking water.

The trophic grade of a certain lake depends on the intensity of matter and energy exchange, i.e. on the organic production. Namely, oligotrophic lakes have small organic production, whereas the shallow waters, among which the lakes are classified too, have high organic production. Such state is preconditioned by: increased water temperature and light penetration down to the bottom, which stimulates the macro-vegetation and the trophicity of water ecosystems (Benndorf, 1992; Moss \& Philips, 1996).

Water Framework Directive (WFD) of European Community $(2000 / 60 / E C)$ is the legal basis for the development of biological monitoring of surface waters in Europe. It raises a number of monitoring requirements, with emphasis on the hydrobiological monitoring and defines the requirements for monitoring the status of surface waters. Biological monitoring as a criterion for assessing ecological quality of water used with priority in many European countries as a mandatory element of the monitoring system and information about the status of water. The concept of ecological status is defined in terms of the quality of the biological community (phytoplankton, macrozoobenthos, and macrophytes), according to the WFD (2000/60/EC) and ecosystem approach philosophy, as well as the hydromorphological and physicochemical characteristics of the system. These indices give possibilities for establish the changes in the water quality and successfully can be used for the purposes of ecological assessment of the river water bodies (Mihailova and Kostadinova, 2012; Kostadinova et al., 2013).

The goal of this paper was to investigate the macrozoobenthos communities in the water of Strezhevo accumulation, Shemnica River and alimentation canal and on this base to assess the ecological status of the water during different seasons of the year.

\section{MATERIAL AND METHODS}

The samples of water and sediment from different water bodies were collected in the period March-October 2009 from monitoring points as follow:
- Strezhevo accumulation: $\mathrm{SI}_{1}, \mathrm{SI}_{2}, \mathrm{SI}_{3}, \mathrm{SII}_{1}$, $\mathrm{SII}_{2}, \mathrm{SIII}_{1}, \mathrm{SIII}_{2}, \mathrm{SIII}_{3}$ );

- Shemnica River: SHR., SHR loc. 1, SHR loc. 2), Shemnica River before mouth (SHRbm), confluence (c.) and the alimentation canal (A.C.);

- alimentation canal under bridge (A.C.b), alimentation canal before confluence (A.C.c).

The bottom fauna samples were being collected using an Eckmann-Birge type excavator with grab area of $132 \mathrm{~cm}^{2}$ and a Surber net with grab area of $300 \mathrm{~cm}^{2}$ (APHA, AWWA, WEF 2005). Using standard methods, the material collected was prepared for further processing in laboratory conditions.

Saprobic index (s) was calculated according to Pantle-Buck model (1955). That index was used to categorized the Strezhevo Lake according established ecological status.

The bottom fauna's qualitative composition is determined based on the taxonomic characteristics of the organisms (Brinkhurst \& Jamieson, 1971).

For Oligochaeta determination the most important thing is the sexual apparatus to be preserved. For that purpose the Oligochaeta are preserved using $70.96 \%$ and $100 \%$ alcohol, and then a drop of methyl-salicylate is added. That's when the Oligochaeta become transparent and are easy to be determined. Oligochaeta determination was performed on live units using standard keys for determining this group of organisms. The number of units is presented as total number of units per square meter (Bartoš, 1959; Šrámek, 1962).

\section{RESULTS AND DISCUSSION}

\section{Fauna of the bottom in winter}

Table 1 shows the qualitative and quantitative composition of the macrozoobenthos, for each location. The analysis of the macrozoobenthos winter sample from the accumulation and part of its confluent basin shows penury regarding the qualitative-quantitative composition. The fauna of the bottom of Shemnica River and the alimentation canal is significantly more diverse in comparison to that of the accumulation studied, and in the latter a uniform fauna of oligochaetic-chironomous type is ascertained with a distinctive prevalence of the Oligochaeta group. This group's representatives are distinctively prevalent in the deeper parts of the lake, towards the dam where the sedimentation is intense. 
Table 1

Qualitative and quantitative composition of the bottom fauna in winter (ind $/ \mathrm{m}^{2}$ )

\begin{tabular}{|c|c|c|c|c|c|c|c|c|c|c|c|c|}
\hline 3. 3. 2009 & $\mathrm{~s}$ & SHR & SHRbm & A.C. & $\mathrm{SI}_{1}$ & $\mathrm{SI}_{2}$ & $\mathrm{SI}_{3}$ & $\mathrm{SII}_{1}$ & $\mathrm{SII}_{3}$ & $\mathrm{SIII}_{1}$ & $\mathrm{SIII}_{2}$ & $\mathrm{SIII}_{3}$ \\
\hline \multicolumn{13}{|l|}{ OLIGOCHAETA } \\
\hline Bythonomus lemani & 1.2 & & 44.44 & 3.33 & & & & & & & & \\
\hline Enhitrus albicus & 2.9 & & & 6.66 & 88.88 & & & & & & & \\
\hline Enhitrus sp. & 2.1 & & & & & & & & & & & \\
\hline Limnodrilusclaperedeanus & 2.9 & & & & & & 222.2 & & & & & \\
\hline Limnodrilus helveticus & 2.9 & & & & & 266.6 & 88.88 & & & & & \\
\hline Limnodrilus hoffmeisteri & 3.6 & 33.33 & & & 44.44 & 133.3 & 44.44 & & & & & \\
\hline L. hoffmeisterif. parva & 3.6 & & & & & & & & & & & \\
\hline Limnodrilus sp. & & & 88.88 & & 44.44 & & & & & & & \\
\hline Nais barbata & 2.8 & & 44.44 & 9.99 & & & & & & & & \\
\hline Nais bretcheri & 2.5 & & 133.3 & & & & & & & & & \\
\hline Nais communis & 2.9 & & & & & & & & & 88.88 & & \\
\hline Nais elinguis & 2.9 & 6.66 & 311.08 & 29.97 & & & & & & & & \\
\hline Nais simplex & 2.7 & & 44.44 & & & & & & & & & \\
\hline Nais stolci & & & 88.88 & & & & & & & & & \\
\hline Nais sp. & 2.9 & & 177.76 & & & & & & & & & \\
\hline Tubifex ignotus & 2.1 & & & & & 222.2 & & & & & & \\
\hline Tubifex tubifex & 3.7 & 6.66 & 44.44 & & & 44.44 & & 44.44 & 133.32 & 1377.6 & 88.88 & \\
\hline \multicolumn{13}{|l|}{ MOLLUSCA } \\
\hline Ancylus sp. & & & & 99.99 & & & & & & & & \\
\hline \multicolumn{13}{|l|}{ DIPTERA } \\
\hline Simuliium sp. & & & 66.66 & 899.9 & & & & & & & & \\
\hline Chironomidae & & & & 66.66 & 133 & 88.8 & & & 88.8 & 888 & & 220 \\
\hline Tanypodinae & & 99.99 & 199.9 & & & & & & & & & \\
\hline Orthocladinae & & 133.3 & & 299.9 & & & & & & & & \\
\hline Chironomus thummi & & & & & & & & & & & 166 & \\
\hline Tipula sp. & & & & 33.33 & & & & & & & & \\
\hline \multicolumn{13}{|l|}{ PLECOPTERA } \\
\hline Lecutra sp. & & 33.33 & & & & & & & & & & \\
\hline Taeniopterygidae & & & & 33.33 & & & & & & & & \\
\hline Taeniopterix sp. & & & & 666.6 & & & & & & & & \\
\hline \multicolumn{13}{|l|}{ EPHEMEROPTERA } \\
\hline Baetis sp. & & 33.33 & 66.66 & 66.66 & & & & & & & & \\
\hline Caenis sp. (horaria) & & & 66.66 & & & & & & & & & \\
\hline Epeorus sylvicola (assimilis) & & & & 99.99 & & & & & & & & \\
\hline Ecdyonurus venosus & & & & 133.3 & & & & & & & & \\
\hline \multicolumn{13}{|l|}{ TRICHOPTERA } \\
\hline Sericostoma sp. & & & & 33.33 & & & & & & & & \\
\hline Sericostomatidae-House & & 33.33 & & & & & & & & & & \\
\hline Hydropsyche instabilis & & & 66.66 & & & & & & & & & \\
\hline Limnephilus sp. & & & 33.33 & & & & & & & & & \\
\hline Saprobity index & & 2.2 & 1.92 & 1.75 & 3.2 & 2.15 & 3.19 & 3.7 & 3.7 & 3.3 & 3.3 & / \\
\hline
\end{tabular}


Table 2

Qualitative and quantitative composition of the bottom fauna in spring (ind/ $\left.\mathrm{m}^{2}\right)$

\begin{tabular}{|c|c|c|c|c|c|c|c|c|c|c|c|c|c|c|}
\hline 12. 5. 2009 & $\mathrm{~s}$ & A.C.b & A.C.cS & HR loc. 1 & HR loc. 2 & c. & $\mathrm{SI}_{1}$ & $\mathrm{SI}_{2}$ & $\mathrm{SI}_{3}$ & $\mathrm{SII}_{1}$ & $\mathrm{SII}_{2}$ & $\mathrm{SII}_{3}$ & $\mathrm{SIII}_{1}$ & $\mathrm{SIII}_{2} \mathrm{SIII}_{3}$ \\
\hline \multicolumn{15}{|l|}{ OLIGOCHAETA } \\
\hline Bythonomu lemani & 1.2 & 88.88 & 177.7 & & & & & & & & & & & \\
\hline Trichodrilus strandi & & 44.44 & & & & & & & & & & & & \\
\hline Limnodrilus udecemianus & 3.8 & & & & & & & & & & & & 755.5 & \\
\hline Limnodrilus hoffmeisteri & 3.6 & & & & & & & 355.5 & 133.3 & 44.44 & & & 1333.2 & \\
\hline Aulodrilus plurisets & 2.2 & & & & & & & & & & 533.3 & & & \\
\hline Nais communis & 2.9 & & 44.44 & & & & & & & & & & & \\
\hline Nais elinguis & 2.9 & 489 & 355 & & & & & & & & & & & \\
\hline Enchytru albidus & 2.9 & 44.44 & & & & & & & & & & & & \\
\hline Lumbriculuss varigatus & 2.3 & 44.44 & & & & & & & & & & & & \\
\hline Eisenel tetraedra & 2.1 & & & & & 88.88 & & & & & & & & \\
\hline Tubifex tubifex & 3.7 & & & & & & & 1338 & & 177.7 & 1777.6 & 400 & 2222 & 400 \\
\hline \multicolumn{15}{|l|}{ MOLLUSCA } \\
\hline Limnaea peregra & 2.0 & & & & & 88.88 & & & & & & & & \\
\hline Ancylu fluvialitis & 1.35 & & & & 88.88 & 44.44 & & & & & & & & \\
\hline \multicolumn{15}{|l|}{ GAMMARIDE } \\
\hline Gammarus sp. & 1.1 & & & & 355 & & & & & & & & & \\
\hline \multicolumn{15}{|l|}{ DIPTERA } \\
\hline Liponeura sp. & & 88.88 & & & & 44.44 & & & & & & & & \\
\hline Chironomidae & & 222.2 & 177 & 311.8 & 133 & 222.2 & & & & & 177 & 88.88 & & \\
\hline Dicronata sp. & & 133 & 88.88 & & & 44.44 & & & & & & & & \\
\hline Myaloptera sp. & & & 44.44 & & & & & & & & & & & \\
\hline Tipula sp. & & & & 44.44 & & 44.44 & & & & & & & & \\
\hline \multicolumn{15}{|l|}{ PLECOPTERA } \\
\hline Isoperla grammatical & 1.75 & 44.44 & & & & 133 & & & & & & & & \\
\hline Perlodes microcephala & 0.3 & 44.44 & & & 88.88 & 44.44 & & & & & & & & \\
\hline Taeniopterix sp. & 0.9 & & 44.44 & 133 & 88.88 & & & & & & & & & \\
\hline \multicolumn{15}{|l|}{ ODONATA } \\
\hline Gomphus vulgatissimus & 2.5 & & & 44.44 & & & & & & & & & & \\
\hline \multicolumn{15}{|l|}{ EPHEMEROPERA. } \\
\hline Ephemer danica & 1.5 & 44.44 & & 88.88 & & & & & & & & & & \\
\hline Epeoru assimilis & 0.55 & & & 177 & 133 & & & & & & & & & \\
\hline Baetis sp. & 1.3 & 133 & 44.44 & 311.1 & 222.2 & 44.44 & & & & & & & & \\
\hline Caenis horaria & 1.1 & & 44.44 & & & & & & & & & & & \\
\hline Ecdyonurus venosus & 2.0 & 44.44 & & 44.44 & 88.88 & 44.44 & & & & & & & & \\
\hline \multicolumn{15}{|l|}{ TRICHOPTERA } \\
\hline Anabolia nervosa & 2.0 & 133 & & & & & & & & & & & & \\
\hline Potamophylax latipenis & & 133 & & 133 & & & & & & & & & & \\
\hline Hydropsyche instabilis & 1.95 & & & 133 & 177 & 133 & & & & & & & & \\
\hline Limnephilus sp. & 1.2 & & & & 444.4 & 311.18 & 88.88 & & & & & & & \\
\hline Odontocerum albacore & 0.1 & & & 44.44 & & & & & & & & & & \\
\hline Limnephilus sp. & 1.2 & & 44.44 & & & & 38.88 & & & & & & & \\
\hline$\underline{\text { Saprobity index }}$ & & 1.82 & 1.65 & 1.15 & 1.17 & 1.75 & 1.2 & 3.65 & 3.8 & 3.65 & 2.95 & 3.7 & 3.7 & 3.7 \\
\hline
\end{tabular}


According to the data obtained, Shemnica River and the alimentation canal before the junction have water characteristics of $\Delta$-mesosaprobic type, with indexes of 2.2 and 1.75, and may be ranked in quality class II (Regulation for Classification of Water, Official Gazette of Republic of Macedonia, 1999).

Water quality in Strezhevo accumulation, according to the analysis of the macrozoobenthos, may be divided in several zones: lithoral part zone in the immediate vicinity of the dam, and the accumulation environment with high saprobic index, therefore these parts of the lake are classified in $\Delta$-mesosaprobic type, with a tendency towards polysaprobity. Only at the point $\mathrm{SI}_{2}$ (the beginning of the accumulation) better water quality is perceived, with saprobity index of 2.15 .

\section{Fauna of the bottom in spring}

In the spring season, 9 groups of invertebrate benthos macrofauna were found on the researched locations of Strezhevo accumulation and part of its confluent basin. Insecta is the most numerous group here. Ecological conditions' diversity in the accumulation's confluent part has preconditioned a corresponding development of the bottom macrofauna (Jeppesen et al., 1997). In qualitative and quantitative terms, insects' fauna prevails in it, being represented mainly by groups and species typical for fast-flowing clear waters with sand/rock substrate (Table 2).
The increased diversity of species of the groups Ephemeroptera, Trichoptera and Plecoptera, the ones being indicators of clean waters, is especially characteristic here. Biodiversity of the benthos macrofauna drastically decreases at the lake's entrance and transforms into a typical lakelike uniform fauna of oligochaetic-chironomus type. Oligochaeta's fauna is more present at the middle points, and especially near the dam. At all the researched profiles the population of Tubifex tubifex species prevails, being the mainstay of Oligochaeta community's numerosity (Vagner \& Mestrov, 1982).

Based on the saprobiological index, it can be ascertained that water quality in the lake's confluent basin is of oligo-beta-mesosaprobic type, whereas the surface layer of the water ranks in alpha to poly-saprobic quality degree.

\section{Fauna of the bottom in summer}

In the summer period the water inflow into the alimentation canal and the river of Shemnica completely dried up. Intense water drainage for irrigation purposes as well as for water supply of the population led to drastic descent of the lake level. In these conditions a uniform benthos macrofauna of invertebrates was ascertained, represented mainly by species from Oligochaeta and Chironomidae groups (Table 3 ).

Table 3

Qualitative and quantitative composition of the bottom fauna in summer (ind $/ \mathrm{m}^{2}$ )

\begin{tabular}{|c|c|c|c|c|c|c|c|c|c|c|}
\hline 8. 8.2009 & $\mathrm{s}$ & $\mathrm{SI}_{1}$ & $\mathrm{SI}_{2}$ & $\mathrm{SI}_{3}$ & $\mathrm{SII}_{1}$ & $\mathrm{SII}_{2}$ & $\mathrm{SII}_{3}$ & $\mathrm{SIII}_{1}$ & $\mathrm{SIII}_{2}$ & $\mathrm{SIII}_{3}$ \\
\hline \multicolumn{11}{|l|}{ OLIGOCHAETA } \\
\hline Limnodrilus offmeisteri & 3.6 & 311.1 & 533.3 & 311.1 & & & & & & \\
\hline Limnodrilus sp. & 3.5 & & 177.7 & 44.44 & & & & & & \\
\hline Tubifex tubifex & 3.7 & 2113.1 & 933.2 & 577.7 & 2888.6 & 3100 & 1022 & 2088.7 & 1886.5 & 1066.5 \\
\hline Aulodrilus pluriseta & 2.2 & & & & & 755.5 & & & & \\
\hline \multicolumn{11}{|l|}{ TURBELARIA } \\
\hline Dugesia sp. & 2.0 & & & & 44.44 & & & & & \\
\hline \multicolumn{11}{|l|}{ ISOPODA } \\
\hline Asellus sp. & 2.4 & & & & 88.88 & & & & & \\
\hline \multicolumn{11}{|l|}{ DIPTERA } \\
\hline Chironomidae & & 222.2 & & & & 222.2 & 355 & 710 & & 44.44 \\
\hline Saprobity index & & 3.65 & 3.65 & 3.65 & 2.7 & 2.95 & 3.7 & 3.7 & 3.7 & 3.7 \\
\hline
\end{tabular}


Within this fauna the species Tubifex tubifex is especially prevalent. The quantums of Oligochaeta and of this prevailing type are equal at all the profiles. These results are similar to the results of Duran \& Akyildiz (2011) who found more Oligochaeta species during the summer period. The autors pointed out that increasing temperatures might support eurithermic spesies.

According to the saprobiological index, the studied contact layer of the lake may be categorized in $\Delta$-polysaprobic zone, which indicates increased presence of biodegradable organic matters.

\section{Fauna of the bottom in autumn}

In the autumn season the lowest water level of the lake was registered. Lake's water withdraws from the flood shore zones and that's why the investigated sites are located closer to the middle of the lake. For that reason the previously ascertained differences in the qualitative and quantitative composition between the shore points and the middle part of the lake don't exist in such conditions, so that the distribution and the abundance of the Oligochaeta communities are evenly present in all parts of the lake. The biggest prevalence at all the profiles is held by the species Tubifex tubifex (Table 4).

Based on the high values of the saprobiological index, increased amounts of organic matters in the contact layer can be ascertained, and for that reason it is ranked in category $\Delta$-mesosaprobic to polysaprobic.

The results gained from determination of macrozoobenthos species are in concordance with the results of Duran (2006) and Slavevska-Stamenković et al. (2008).

All these results are a signal portending serious deterioration of water quality in the ecosystem studied.

Table 4

Qualitative and quantitave composition of the bottom fauna in autumn (ind/ $\mathrm{m}^{2}$ )

\begin{tabular}{|c|c|c|c|c|c|c|c|c|c|c|}
\hline 11.10 .2009 & $\mathrm{~s}$ & $\mathrm{SI}_{1}$ & $\mathrm{SI}_{2}$ & $\mathrm{SI}_{3}$ & $\mathrm{SII}_{1}$ & $\mathrm{SII}_{2}$ & $\mathrm{SII}_{3}$ & $\mathrm{SIII}_{1}$ & $\mathrm{SIII}_{2}$ & $\mathrm{SIII}_{3}$ \\
\hline \multicolumn{11}{|l|}{ OLIGOCHAETA } \\
\hline Limnodrilus Hoffmeisteri & 3.6 & & & & & 177.7 & & & & \\
\hline Limnodrilus sp. & 3.5 & 88.88 & & & & & 488.8 & & 44.44 & \\
\hline Tubifex tubifex & 3.7 & 577.7 & 3377 & 6177.1 & 4977 & 222.2 & 1155 & 4888 & 88.8 & 1422 \\
\hline Aulodrilus pluriseta & 2.2 & & 133.3 & 844.4 & 666.6 & & & & & \\
\hline Limnodrilus Udecemianus & & & & & 1022 & & & & & \\
\hline Stylodrilus lacustris & & & & & & & & & 222.2 & \\
\hline Trichodrilus strandi & & & & & & & & & 44.44 & \\
\hline \multicolumn{11}{|l|}{ TURBELLARIA } \\
\hline Dugesia sp. & 2.0 & & & & & 44.44 & & & & \\
\hline Bivalvia & & & 133.3 & & & & & & & \\
\hline \multicolumn{11}{|l|}{ DIPTERA } \\
\hline Chironomidae & & & 1866.5 & 3066 & 4311 & & 1022 & 1866.5 & & 488.8 \\
\hline Saprobity Index & & 3.6 & 2.95 & 2.95 & 3.2 & 3.1 & 3.6 & 3.7 & 3.6 & \\
\hline
\end{tabular}

\section{CONCLUSION}

Water quality in Strezhevo accumulation, according to the analysis of the macrozoobenthos, in the winter period may be divided in several zones: lithoral part - zone in the immediate vicinity of the dam, and the accumulation environment with high saprobic index, therefore these parts of the lake are classified in $\Delta$-mesosaprobic type, with tendency towards polysaprobity. Only at the point $\mathrm{SI}_{2}$ (the beginning of the accumulation) better water quality is perceived, with saprobity index of 2.15 . 
In the spring period, based on the saprobiological index it can be ascertained that water quality in the lake's confluent basin is of oligo-betamesosaprobic type, whereas the surface layer of the water ranks in alpha to polysaprobic quality degree.

According to the saprobiological index, the studied contact layer of the lake in the summer period may be categorized in $\Delta$-polysaprobic zone, which indicates increased presence of biodegradable organic matters in summer.

Based on the high values of the saprobiological index in the autumn period, increased amounts of organic matters in the contact layer can be ascertained, and for that reason it is ranked in category $\Delta$-mesosaprobic to polysaprobic.

\section{REFERENCES}

[1] APHA, AWWA, WEF: Standard Methods for the Examination of Water and Wastewater (2005).

[2] Bartoš Emanuel: Fauna ČSR, sv. 15, Viřníci-Rotatoria, Československá akademie věd, Praha, 1959.

[3] Benndorf J.: The control of the indirect effects of biomanipulation. In: Sutcliffe D. W. \& Jones J. G. (eds), Eutrophication: Research and Application to Water Supply, Freshwat. Biol. Association, Far Sawrey, Ambleside, Cumbria, England, 1992.

[4] Brinkhurst R. O., Jamieson B. G.: Aquatic Oligochaeta of the World. 860 pp., 1971.

[5] Duran M.: Monitoring water qulity using benthic macroinvertebrates and physicochemical parameters of Behzat Stream in Turkey. Polish J. of Environ. Stud., 15 (5): 709-717 (2006).
[6] Duran M., Akyildiz G. K.. Evaluating benthic macroinvertebrate fauna and water quality of Suleymani Lake (Buldan-Denizli) in Turkey. Acta Zool. Bulg., 63 (2): 169-178 (2011).

[7] Jeppesen E., Jensen J. P., Sondegaard M., Lauridsen T., Pedersen L. J., Jensen L.: Top-down control in fresh water lakes: the role of nutrient state, submerged macrophytes and water depth, Hydrobiologia 342/343: 151-164 pp. (1997).

[8] Kostadinova G. N., Georgieva Z., Yaneva G., Petkov M., Todorova Miteva Ch.: Tundzha river water quality as a source for irrigation in agriculture. Bulgarian Journal of Agricultural Science, 19 (4): 635-643 (2013).

[9] Mihailova G., Kostadinova G.: Macrozoobenthos Communities as Indicator for Ecological Status Assessment of Surface Water Bodies in Toundja River, Bulgaria, Journal of Balkan Ecology, 15 (2): 173-190 (2012).

[10[ Moss B., Stansfield J. H., Irvine K., Perrow M. R., Philips G. L.: Progressive restoration of a shallow lake, a twelveyear experiment in isolation, sediment removal and bioma nipulation, J. Appl. Ecol. 33: pp. 71-86 (1996).

[11] Pantle R., Buck H.: Die biologische Ueberwachung der Gewaesser und die Darstellung der Ergebnisse. Gas und Wasserfach, 96, 604 (1955).

[12] Regulation for Classification of Water. Official Gazette of Republic of Macedonia No. 18, 1165 (1999).

[13] Smiljkov S., Slavevska-Stamenković V., Prelić D., Paunović M.: Distribution of benthic macroinvertebrates in Mantovo Reservoir (South-East part of the R. Macedonia). (BALWOIS). http://balwois.com/balwois/ administration/full_paper 181.pdf (2008).

[14] Šrámek-Hušek Rudolf, Straskraba Milan, Brtek Ján.: Fauna ČSSR, sv. 16. Lupenožci - Branchyopoda. ČAV, Praha (1962).

[15] Vagner D., Mestrov M.: Distribution and Ecological Dependence of Oligochaeta (Annelida, Clitellata) populations of the River Vrbas, Glasnik Zemaljskog muzeja N.S. sv.: Prirodne nauke, Sarajevo. 103-117 (1982). 